\title{
Activities of Alpha Amylase in Serum and Saliva of Some Nigerian Cigarette Smokers
}

\author{
Onyesom I. ${ }^{1}$, Osioma E., ${ }^{2, *}$ Ifie E. J. ${ }^{1}$, Oweh O. T. ${ }^{1}$ \\ ${ }^{1}$ Department of Medical Biochemistry, Delta State University, Abraka, Nigeria \\ ${ }^{2}$ Department of Biochemistry, Faculty of Science, University of Ilorin, Nigeria
}

\begin{abstract}
This study reports the effect of cigarette smoking on serum and salivary $\alpha$-amylase activities of some consenting Nigerian male smokers (20) in apparent good health and between 30 to 70 years. Age and sex-matched non-smokers (20) were included as control subjects. Alpha amylase activity was assayed using standard colorimetric method. Results obtained show that the mean $\alpha$-amylase activity in serum and saliva were significantly higher $(P<0.05)$ in smokers $(131.2 \pm$ $17.0 \mathrm{IU} / \mathrm{L}$ and $241.8 \pm 23.6 \mathrm{IU} / \mathrm{L})$ when compared with non-smokers $(68.3 \pm 11.3 \mathrm{IU} / \mathrm{L}$ and $133.5 \pm 8.6 \mathrm{IU} / \mathrm{L})$, and these represent $84.3 \%$ and $95.2 \%$ increases in serum and saliva values for the smokers relative to the non-smokers. Evidence from this study indicates a measure of pancreatic, salivary and parotid glands' dysfunction among the cigarette smokers in Nigeria. Measurement of serum and salivary $\alpha$-amylase activity could be useful in the early detection and diagnosis of pancreatitis and parotitis.
\end{abstract}

Keywords $\quad \alpha$-Amylase, Saliva, Cigarette, Pancreatitis, Smokers

\section{Introduction}

Nicotine, a major component of cigarette could be absorbed in the mouth, and along with other cigarette compounds has been observed to increase the risk of pancreatic cancer[1].

Commercially manufactured cigarettes are seemingly simple objects consisting of mainly tobacco blend which may contain over 100 ingredients including tar and flavourants. Tar, a term used to describe the toxic chemicals found in cigarette is present in all cigarettes and tends to increase as the cigarette is burnt down. Tar in cigarette paralyzes the cilia in the lungs and contribute to lung diseases such as ephysema, bronchitis, lung cancer, etc[2].

Alpha amylase in animals is a major digestive enzyme with optimum $\mathrm{p}^{\mathrm{H}}$ of 6.7-7.0. It is secreted by the salivary gland and pancreas, and so present in saliva and serum. $\alpha$ -amylase is known for its role in the breakdown of large insoluble starch molecules into smaller, soluble molecules. Salivary $\alpha$-amylase has been used as a biomarker for stress that does not require a blood draw[3].

The effects of cigarette smoking on lung[4] and cardiovascular[5] functions are well documented, but the changes in serum and salivary $\alpha$-amylase activities among cigarette smokers have remained scarce in our society. This present study therefore, attempts to report the activities of

* Corresponding author:

ejoviosioma@yahoo.com (Osioma E.)

Published online at http://journal.sapub.org/als

Copyright (C) 2012 Scientific \& Academic Publishing. All Rights Reserved $\alpha$-amylase in serum and saliva of some Nigerian cigarette smokers.

\section{Materials and Methods}

Subjects: Twenty male cigarette smokers in apparent good health were selected as test subjects from the smoking population. They smoke 2-8 sticks daily, and have been smoking for between 2-20years. Also, twenty individuals who do not smoke or drink alcohol were included as the control subjects. The smokers smoke all brands of cigarette in their locality although some have preference for Benson and Hedges ${ }^{(\mathrm{R})}$.

Sample Collection: Blood and saliva samples were collected from the volunteers ( 20 smokers and 20 non-smokers) in apparent good health. Two milliliters $(2 \mathrm{ml})$ of whole blood samples were collected from the subjects using the vene puncture technique and dispensed immediately into a plain, sterile bottle, centrifuged at $1200 \times \mathrm{xg}$ for $5 \mathrm{~min}$ at room temperature to get approximately $1.5 \mathrm{ml}$ of serum.

Saliva samples were collected in sterile containers fresh and analyzed within 6 hours of collection. Data obtained were expressed as Mean \pm S.D.

Sample Analysis: The activity values of both serum and salivary $\alpha$ - amylase were determined by the p- nitrophenylheptaoside colorimetric method[6] using freshly reconstituted commercial reagent supplied by Randox Laboratories; Ardmore, UK.

Statistics: Student's ' $t$-Test' was used to compare the calculated means of the parameters and the differences be- 
tween mean values were considered significant at the $5 \%$ probability level.

\section{Results}

The results obtained are presented on Tables 1,2 and 3.

Table 1. $\alpha$-amylase activity in salvia and serum of cigarette smokers

\begin{tabular}{|c|c|c|}
\hline Subjects & \multicolumn{3}{|c|}{$\alpha$-Amylase activity (IU/L) } \\
\hline & Saliva & Serum \\
\hline Non-smokers $(\mathrm{n}=20)$ & $133.5 \pm 8.6$ & $68.3 \pm 11.3$ \\
\hline Smokers(n=20) & $241.8 \pm 23.6^{*}$ & $131.2 \pm 17.0^{*}$ \\
\hline & $(95.2 \%)$ & $(84.3 \%)$ \\
\hline
\end{tabular}

Values are expressed as Mean \pm S.D, *Significantly

$(\mathrm{P}<0.05)$ different from control value. Percentage increases are written in parenthesis.

Table 2. Effect of age and cigarette smoking duration on serum and salivary $\alpha$-amylase activity values

\begin{tabular}{|c|c|c|c|}
\hline \multicolumn{4}{|c|}{$\begin{array}{c}\text { Smokers non -smokers } \\
\text { Smoking duration 5-10 11-20 (Yr) }\end{array}$} \\
\hline \multicolumn{4}{|c|}{ Age (yrs) Changes in serum $\alpha$-amylase (IU/L) activity values } \\
\hline $30-54$ & $132.0 \pm 19.9$ & $138.5 \pm 23.2$ & $66.2 \pm 12.7^{*}$ \\
\hline $55-70$ & $130.5 \pm 12.0$ & $135.5 \pm 20.1$ & $70.4 \pm 9.8^{*}$ \\
\hline Average & $31.3 \pm 15.9$ & $137.0 \pm 21.7$ & $68.3 \pm 11.3^{*}$ \\
\hline \multicolumn{4}{|c|}{ Changes in salivary $\alpha-$ amylase (IU/L) activity values } \\
\hline $30-54$ & $239.1 \pm 19.9$ & $250.0 \pm 0.7$ & $133.5 \pm 8.6$ \\
\hline $55-70$ & $234.0 \pm 28.3$ & $253.8 \pm 35.2$ & $138.6 \pm 5.4$ \\
\hline Average & $236.6 \pm 24.1$ & $251.9 \pm 17.9$ & $136.1 \pm 7.0$ \\
\hline
\end{tabular}

Values are expressed as Mean $\pm \mathrm{SD}$

Table 3. Changes in serum and salivary $\alpha$-amylase (IU/L) activity values induced by cigarette smoking rates in different age groups

\begin{tabular}{|c|c|c|c|}
\hline \multicolumn{4}{|c|}{$\begin{array}{l}\text { Smokers 0non-smokers } \\
\text { Smoking rate } \\
\text { (sticks/day) } 1-4 \text { 5-8 }\end{array}$} \\
\hline \multicolumn{4}{|c|}{ Age (yrs) Changes in serum $\alpha$-amylase (IU/L) activity values } \\
\hline $30-54$ & $137.4 \pm 20.4$ & $125.3 \pm 17.5$ & $66.2 \pm 12.5^{*}$ \\
\hline $55-70$ & $131.4 \pm 11.5$ & $126.2 \pm 15.0$ & $70.4 \pm 9.8^{*}$ \\
\hline Average & $134.2 \pm 15.9$ & $125.8 \pm 16.3$ & $68.3 \pm 11.3^{*}$ \\
\hline \multicolumn{4}{|c|}{ Changes in salivary $\alpha$-amylase (IU/L) activity values } \\
\hline $30-54$ & $234.8 \pm 21.1$ & $253.0 \pm 15.9$ & $133.5 \pm 8.6^{*}$ \\
\hline $55-70$ & $241.3 \pm 19.0$ & $244.8 \pm 36.1$ & $138.6 \pm 5.4^{*}$ \\
\hline Average & $238.1 \pm 20.1$ & $248.9 \pm 26.0$ & $136.1 \pm 7.0^{*}$ \\
\hline
\end{tabular}

Values are expressed as Mean $\pm \mathrm{SD}$.

The mean serum $\alpha$-amylase activity value was higher for the test (smokers) subjects than the control (non-smokers) individuals. This difference was demonstrated to be statistically significant at the $5 \%$ probability level using ANOVA. Similarly, the mean $\alpha$-amylase activity value in the saliva of the control was significantly lower than that of the cigarette smokers.

The mean serum $\alpha$-amylase activity values for cigarette smokers were higher than the non-smokers values and these differences were statistically significant $(p<0.05)$.

Subjects' age did not significantly influence serum $\alpha-$ amylase activity values, but among the smokers, smoking duration affected values significantly $(P<0.05)$. The higher the smoking duration, the higher the serum $\alpha$-amylase activity values
Similar trend was observed for the changes in salivary $\alpha$ -amylase activity values, but values were seen to be proportionately higher when compared with serum figures.

The higher the rate of cigarette smoking the lower the serum $\alpha$-amylase activity value irrespective of the age group. But a reversed pattern was observed for the changes in salivary $\alpha$-amylase activity values.

\section{Discussion}

Present data show that there were significant increases $(P<0.05)$ in the $\alpha$-amylase activity values in both serum and saliva of cigarette smokers, when compared with non-smokers (Table 1).The age of smokers, rate of smoking and the duration of smoking (Tables 2 and 3 ) did not significantly alter the $\alpha$-amylase activity values in either serum or saliva, although there were significant differences (increases) when compared with the values for non-smokers.

Earlier studies reveal that cigarette smoking causes an increase in both serum and saliva $\alpha$ - amylase activity value[7]. In smokers, basal serum amylase activity values has been observed to be $100 \%$ higher than the non-smokers' value[8]. In this study, smokers serum and salivary $\alpha-$ amylase activity values were $84.3 \%$ and $95.2 \%$ higher than the non-smokers' values.

Also, passive smoking has been shown to be associated with an increase in salivary amylase activity in young children[9]. These demonstrated increases have been contradicted by other workers. Some researchers report that smoking cigarette does not affect the $\alpha$-amylase activity value in serum and saliva.

[10], studied the effects of smoking habit on salivary amylase and reported that cigarette smoking does not have any significant influence on salivary amylase activity in the subjects. Also, [11] stated that the degree of amylase activity in the saliva of people who smoke cigarette was not significantly different from that present in the saliva of non-smokers.

Several studies suggest that nicotine (which is a major component of cigarette) account for the increase in $\alpha-$ amylase activity in people who smoke cigarette. [12], reports that after intravenous infusion of nicotine into some volunteers, an increase in the salivary amylase activity was observed. Acute administration of nicotine to non-smokers was associated with increased salivary amylase activity[12]. Nicotine has been found to significantly decrease the release of amylase from pancreatic cells (acini) in response to hormones (insulin and cholecystokinin) and to significantly increase the amount of amylase present in the cells[13]. The authors of this last study proposed that these effects of nicotine may account for the increased incidence of pancreatitis and pancreatic cancer in people who smoke.

Increased serum $\alpha$-amylase may indicate pancreatitis. Serum amylase is increased at least in $75 \%$ pancreatitis cases. Although, serum amylase measurement is not the measurement for diagnosing pancreatitis. Chronic pancreatitis has 
been linked to cigarette smoking which cause an increase in the $\alpha$-amylase activity value[14]. Pancreatitis is inflammation of the pancreas which can either be acute or chronic. Also, knowing that the pancreas (endocrine) produces hormones such as insulin, which helps to regulate the amount of sugar circulating in the blood, then problems with insulin production can lead to glucose intolerance and diabetes mellitus.

Individuals with serum amylase level higher than normal could be suffering from renal insufficiency or nephrectomy. Also, high serum amylase activity has been observed in hepatic necrosis and cirrhosis[15] hence the liver is thought to play a role in amylase metabolism. Thus, increase in serum or salivary amylase could be as a result of decreased metabolic clearance of amylase, pancreatitis or parotitis.

Parotitis is a salivary disease that is associated with increase in S-type isoamylase. Parotitis is usually caused by trauma, stress or surgery to the salivary gland, radiation to the neck area involving the parotid gland and subsequently causing duct obstruction, or calculi of the salivary duct.

Evidence show a measure of asymptomatic pancreatic, salivary and parotid glands' dysfunction among the cigarette smokers. Determination of both salivary and serum $\alpha-$ amylase activities could be valuable in detecting pancreatic and parotid/salivary gland diseases at early stage. Overall, cigarette smokers have considerable risk of developing such diseases as judged by their significant increases in both serum and salivary $\alpha$-amylase activity values.

\section{REFERENCES}

[1] Talamini, G. (2005). Duodenal acidity may increase the risk of pancreatitis: An Etiopathogenic hypothesis. J. Pancr: 6(2): 122-127.

[2] Martins, T. (2008) Tar in cigarettes. Toxic chemicals in cigarettes www.quitsmoking.about.com/od/chemicalsinsmoke/g/ tar. Accessed on February 13th 2008.

[3] Yuka, N., Tetsumi, S., Mihoko, K., Kiyoshi, K. and Kuzuyoshi, H. (2005). The relationship between salivary biomarkers and state-trait anxiety inventory score under mental arithmetic stress. A pilot study. Anesth Analg 101 (6):
1873-1876.

[4] Diane, R.G., Xiaobin, W., David, W., Frank, E. S., James, H, W. and Douglas, W,D. (1996) Effects of cigarette smoking on lung function in adolescent boys and girls N. Eng.l J Med. 335: 931-937.

[5] Ambrose, J.A and Barua, R.S. (2004). The pathophysiology of cigarette smoking and cardiovascular disease. An update $J$. Am. Coll. cardiol 43(10): 1731-1737.

[6] Richard, A.K. and Norbert, W.T (1980) Recent advances in measurement of amylase activity. Clin Chem. 28 (7): 846-857.

[7] Nater, U.M., Rohleder, N., Schlotz, W., Ehlert, U. and Kivschbaum, C. (2007). Determinants of the diurnal course of salivary alpha amylase. Psychoneuro endocrine 32 (4): 392-401.

[8] Dubick, M.A., Contens, C.N., Billy, H.A., Majumdar A.P. and Geokas, M,C. (1987) Raised serum concentration of pancreatic enzymes in cigarette smokers. Gut: 28 (3) 330-350.

[9] Avsar, A., Darke, O., Bodrumlu, E. and Bek, Y. (2009) Evaluation of the relationship between passive smoking and salivary electrolytes, protein, secretory $1 \mathrm{gA}$, silaic acid and amylase in young children. Arch Oral Biol. 54(5) 457-463.

[10] Nagaya, T. and Okuno, M. (1993). No effect of smoking on drinking habits on salivary amylase. Toxicol. Lett. 66 (3): 257-261

[11] Kivela, J., Parkkila, S., Parkkila, A., Rajaniemi, H. and Leinonen, J. (1997). Salivary carbonic anhydrate VI concentration and its relation to basic characteristics of saliva in young men. Acta. Physiol. Scand 161 (2): 221-225.

[12] Maier, H., Jarczyk, L., Scherev, G. and Born, I.A. (1991). Effects of acute nicotine application on the function of the human parotid gland. Laryngo - Rhino - otologie. 70 (1): 24-26.

[13] Chowdhury, P., Maccleod, S., Udupa, B.K. and Rayfrod, L.P. (1995). Structural and functional changes of rat exocrine pancreas-exposed to nicotine. Int'l $J$ Pancreatol. 18(3):257-265.

[14] Maisonneuve,P., Lowenfels, A.B. and Muuhaupt, B. (2004). Cigarette smoking accelerates progression of alcoholic chronic pancreatitis. Gut 54: 510-514.

[15] Rueff, B. and Bentamou, J.P. (1973) Acute hepatic necrosis and fulminant hepatic failures. Gut 10: 805-815. 